\title{
Detecting successional changes in long-term empirical data from subalpine conifer forests
}

\author{
Anita C. Risch ${ }^{1, *}$, Martin Schütz ${ }^{1}$, Bertil O. Krüsi ${ }^{1}$, Felix Kienast ${ }^{1}$, Otto Wildi ${ }^{1}$ and \\ Harald Bugmann ${ }^{2}$ \\ ${ }^{1}$ Swiss Federal Institute for Forest, Snow and Landscape Research, Zuercherstrasse 111, 8903 Birmensdorf, \\ Switzerland; ${ }^{2}$ ETH Zurich, Mountain Forest Ecology, Department of Forest Sciences, Rämistrasse 101, 8092 \\ Zürich, Switzerland; *Author for correspondence (tel.: +41 173922 30; fax: +41 173922 15; e-mail: \\ anita.risch@wsl.ch)
}

Received 15 April 2002; accepted in revised form 23 May 2003

Key words: Central European Alps, Forest stand, Mountain pine, Successional development, Swiss National Park, Swiss stone pine

\begin{abstract}
In many mountain regions, traditional agriculture and forestry are no longer economically viable and less intense land-use is becoming more and more widespread. Thus, the importance of understanding secondary succession in these abandoned systems increases. This study is based on a comparison of historic (1957) and present tree data (2001) from subalpine forest stands located in the Swiss National Park (SNP), where all management was stopped in 1914. The two data sets contain information on tree and sapling density as well as diameter distribution for all tree species present. Using time-series analyses, space for time substitution and multivariate methods (PCoA, minimum spanning tree analysis), we investigated if successional changes can be detected within the forest stands in the SNP. Our results showed that the stands studied are developing from a stage dominated by mountain pine (Pinus montana Miller) to a late successional stage dominated by Swiss stone pine (Pinus cembra L.) and European larch (Larix decidua Miller). This shift in species composition, which was observed in both the tree and sapling layer, was accompanied by a significant decrease in tree density (stems/ha). We also found that stand disturbances, such as fungal diseases, parasitic insects, ungulate browsing, windthrow or snow pressure, have not prevented succession from mountain pine to Swiss stone pine-larch communities. The minimum spanning tree analysis revealed that the sixteen observed 44-year-time-series cover at least 110 years of succession. This time frame is the shortest possible duration for a successional development starting from a 95 to 125 -yearold mountain pine stand. The successional changes depicted in our study indicate how similar areas in the Central European Alps might develop in the near future when management ceases.
\end{abstract}

\section{Introduction}

In many mountain regions of Europe, traditional agriculture and forestry have been practiced for hundreds of years. However, with recent changes in the economy, these practices are no longer viable in many of these areas, and traditional agricultural and silvicultural land-uses are unlikely to be continued in many places (Price 1995; Riederer 1996; Bäntzing 1996; Broggi 1998). Therefore, the interest in understanding vegetation development in absence of human intervention has increased considerably over the past decades. It is difficult, however, to assess the long-term development of abandoned or less intensively used ecosystems, especially in Western Europe, 
where only few areas exist that were not managed over longer time periods.

The Swiss National Park (SNP) is one of the few areas in Western Europe that was not influenced directly by humans during most of the $20^{\text {th }}$ century. Therefore, the Park provides a unique opportunity to study how no longer managed mountain forests may develop in the absence of human intervention. This development, which may take place over large parts of the Alps in the near future, started in the SNP in 1914. Fortunately, long-term data on grassland and forest development of this area are available for an 85-year and 45-year period, respectively. While secondary succession of grasslands has been the focus of numerous studies (Krüsi et al. 1996; Bärlocher et al. 2000; Märki et al. 2000; Achermann et al. 2000; Schütz et al. 2000a,b,c; Risch et al. 2001), only few have focused on successional processes within the forested areas of the Park (Kienast et al. 1999; Krüsi and Moser 2000). It is known that large parts of the forests were clear-cut several times between the $16^{\text {th }}$ and $19^{\text {th }}$ century (Parolini 1995). Most of these clearcuts regenerated to mountain pine (Pinus montana Miller) dominated forests. Selective timber extraction was maintained within the Park's forests until 1914, but was stopped entirely after the foundation of the Park. Today, mountain pine forests occupy large parts of the SNP, but some slopes are covered with stands dominated by Swiss stone pine (Pinus cembra L.) or a mixture of Swiss stone pine and European larch (Larix decidua Miller). The latter two forest types represent the late stages of subalpine forest succession in this region (Kurth et al. 1960; Holtmeier 1990; Zoller 1995; Kienast et al. 1999).

It is not known, however, whether the forests that are currently dominated by mountain pine will ever reach a late successional stage, or if disturbances such as fungal diseases, parasitic insects, ungulate browsing, windthrows and snow pressure incidents will keep these forests in an early to mid successional stage. Dobbertin et al. (2001), for example, reported that infection by root rot fungi (Heterobasidion annosum (Fr.) Bref., Armillaria spp.) led to a partial breakdown within mountain pine stands, which could significantly impact secondary succession within the Park. In contrast, Krüsi and Moser (2000) observed that snow pressure and ungulate browsing in the SNP only marginally affected the successional development within a mountain pine stand.

Based on succession theory (Clements 1936; Watt 1947; Gleason 1926) and existing knowledge on lo- cal biotic and abiotic forces (Kurth et al. 1960, Krüsi and Moser 2000; Dobbertin et al. 2001), we developed a forest succession scheme for the forests in the Park (Figure 1). Since an extensive database on the tree and sapling composition of the stands in the SNP exists for the year 1957 (Kurth et al. 1960), we have the opportunity to investigate how the forests developed over time, and to check our theoretical succession scheme based on long-term data. Therefore, the overall objective of this study is to investigate successional patterns based on long-term empirical forest stand data (trees and saplings) in conifer forests of the SNP. Specifically, we address the following questions: i) Are we able to detect succession from mountain pine to Swiss stone pine or to Swiss stone pine/larch forests? ii) Which of the theoretically possible successional changes postulated in Figure 1 can we support with empirical evidence? iii) If forest succession is taking place, how much time is needed to reach the late successional stage?

\section{Study Area}

The SNP is located in the southeastern part of Switzerland, covering an area of approximately $170 \mathrm{~km}^{2}$ (Figure 2); $50 \mathrm{~km}^{2}$ are comprised with forests, $33 \mathrm{~km}^{2}$ with alpine grasslands, and $3 \mathrm{~km}^{2}$ with subalpine grasslands, while ice, snow and rocks occupy the other half of the Park. The elevation of the area ranges from 1350 to 3170 meters above sea level (m a.s.1.). A meteorological station located in the Park (Buffalora, $1977 \mathrm{~m}$ a.s.1.) recorded a mean annual precipitation of $925 \pm 162 \mathrm{~mm}$ (average \pm standard deviation) and a mean annual temperature of $0.2 \pm$ $0.7{ }^{\circ} \mathrm{C}$ between 1917 and 1998. The Park's forests are composed of five conifer species. Most abundant are mountain pine, Swiss stone pine and European larch, while Scots pine (Pinus sylvestris L.) and Norway spruce (Picea abies (L.) H. Karst) occur less frequently (Zoller 1995). Scots pine is not competitive in the cold, high elevation forests found in the SNP (Keller et al. 1998), while Norway spruce is not well adapted to the central alpine climate with relatively low rainfall and mean annual temperatures below $1.5^{\circ} \mathrm{C}$ (Ellenberg 1996). 

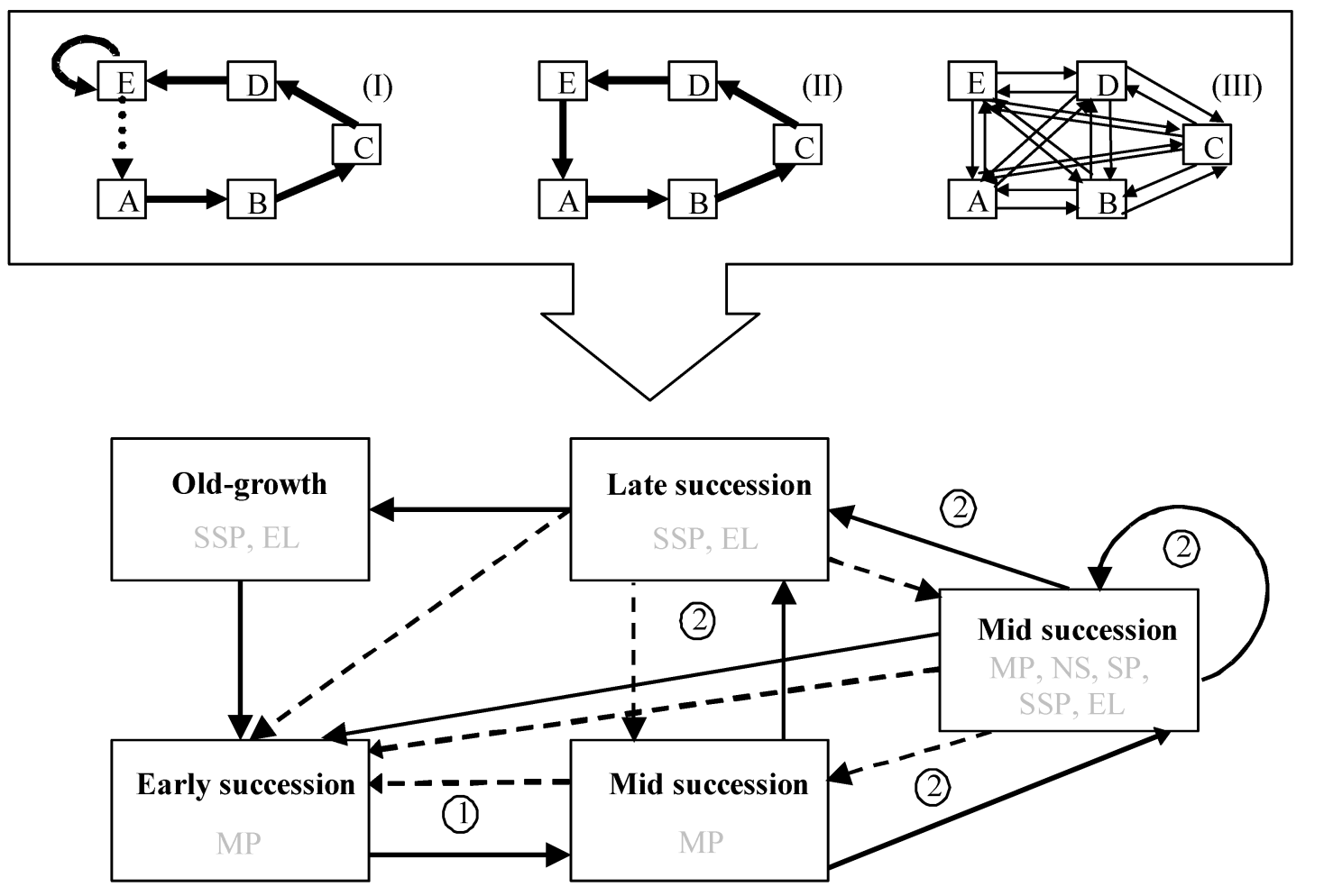

(1) Intraspecific competition, competition for light and resources

(2) Intra- and interspecific competition, competition for light and resources

$\rightarrow$ Distrubances

Major successional changes

Figure 1. Theoretical models of succession. Upper part: Different schemes of succession theory: (I) convergent model by Clements (1936), (II) cyclic model by Watt (1947), (III) largely stochastic, less predictable model by Gleason (1926). Lower part: Theoretical successional forest stages within the SNP. Driving factors are disturbances, intra- and interspecific competition as well as competition for light and other resources. The dominating tree species of each successional stage are shown: MP $=$ mountain pine, SSP $=$ Swiss stone pine, NS $=$ Norway spruce, $\mathrm{EL}=$ European larch, $\mathrm{SP}=$ Scots pine.

\section{Methods}

Historical data and design for sampling present data

In 1957, Kurth et al. (1960) established a sampling design for the entire forested area of the SNP, excluding avalanche runs. They collected data on stand structure and stand composition on circular plots around the intersections of a systematic $143 \mathrm{~m} \mathrm{x} 143$ $\mathrm{m}$ grid, resulting in an extensive database. In this database all information on saplings $(21$ to $130 \mathrm{~cm}$ ) and trees $(>1.3 \mathrm{~m})$ was aggregated to the stand level.
For trees taller than $1.3 \mathrm{~m}$, diameter at breast height (DBH) was recorded (Kurth et al. 1960). Only the stand-level data are available today, but not the plotlevel (grid-point level) data. This database forms the historical basis for our study.

In 2001, we re-sampled 16 of the 131 stands delineated by Kurth et al. (1960) in 1957. They were located within an area of approximately $80 \mathrm{~km}^{2}$ in the center of the Park. Elevations ranged from 1700 to $2200 \mathrm{~m}$ a.s.l. In 1957 the forested area was covered with $73 \%$ mountain pine forests (Erico-Pinetum montanae and Rhododendro hirsute-Pinetum montanae), $11 \%$ Swiss stone pine/larch forests (Larici- 


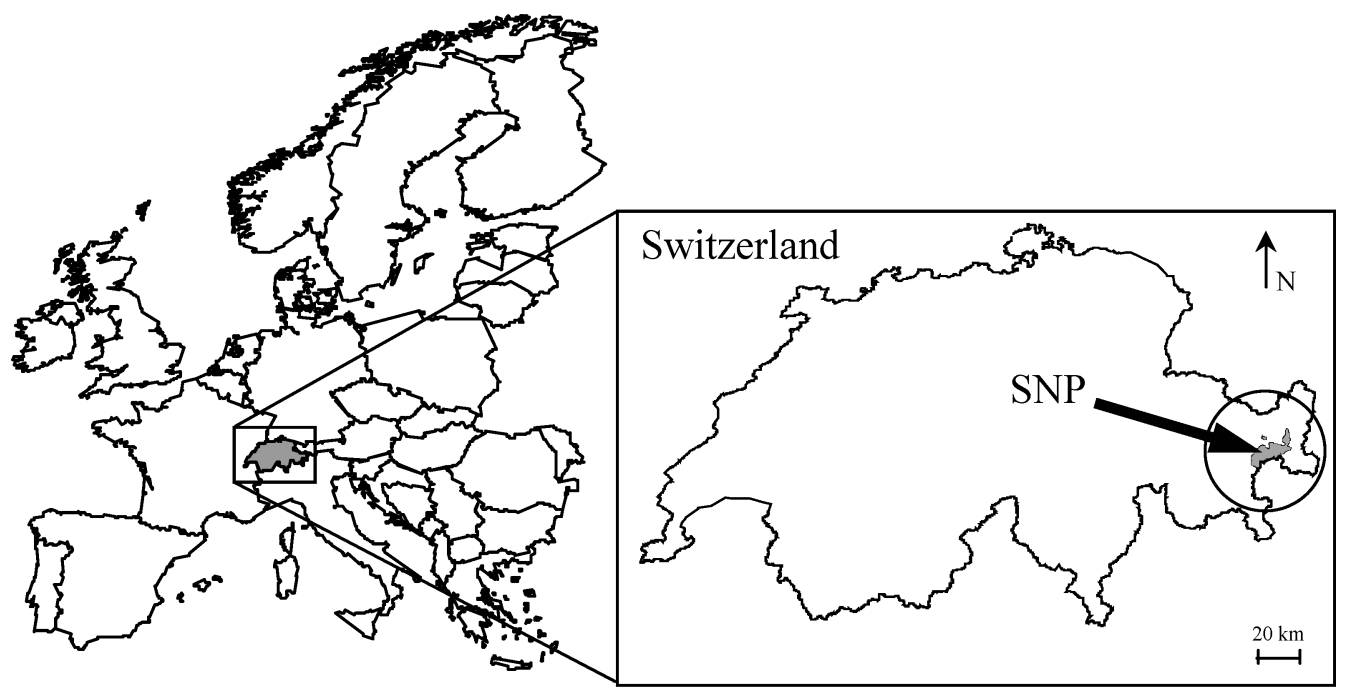

Figure 2. Location of the study area. The Swiss National Park (shaded) is located in the southeastern part of Switzerland.

Pinetum cembrae), and $16 \%$ different, not clearly defined forest and shrub communities (Kurth et al. 1960; Keller et al. 1998). Using the stratified forest stands in the 1957 survey, 16 stands were randomly selected based on the dominant tree species. Twelve stands were dominated by mountain pine, three stands by stone pine or Swiss stone pine/larch, and one stand by both mountain pine and Swiss stone pine. Since the sapling layer of a forest is important for predicting future species composition, the twelve mountain pine stands were split in three groups of four stands each, based on the number of late successional Swiss stone pine saplings observed per hectare in $1957(0$, 1-99, and 100-999).

In each of the 16 stands we sampled 16 points using the point-centered quarter method (Greig-Smith 1983) on a systematic grid of $70 \mathrm{~m} \times 70 \mathrm{~m}$ or $40 \mathrm{~m} \mathrm{x}$ 40 meters, depending on stand size. At each of the 16 points, four trees taller and four trees shorter than 1.3 $\mathrm{m}$ were sampled separately. Species name, distance to the sample point $(\mathrm{m}), \mathrm{DBH}(\mathrm{cm})$ (for trees taller than $1.3 \mathrm{~m}$ only), age (for trees taller than $1.3 \mathrm{~m}$, increment core of two of the four trees per point) and height (m) (using a clinometer) were recorded. Species names follow Lauber and Wagner (1996).

\section{Numerical analyses}

We calculated the number of stems per hectare for different DBH classes for trees taller than $1.3 \mathrm{~m}(0=$ $1-4 \mathrm{~cm} ; 1=5-9 \mathrm{~cm} ; 2=10-19 \mathrm{~cm} ; 3=$
$20-29 \mathrm{~cm} ; 4=30-49 \mathrm{~cm} ; 5=>50 \mathrm{~cm})$ per species and stand as well as the number of saplings $(20-130 \mathrm{~cm})$ per hectare for both years of observation. Since the 1957 and 2001 data were collected within the same 16 stands, the paired data sets (1957 and 2001) represent 16 time series. In order to increase the temporal resolution of these time series, we calculated three intermediate relevés per stand by linear interpolation. In a first step, we carried out a principal co-ordinate analysis (PCoA) using untransformed data and van der Maarel's resemblance measure (Wildi and Orlóci 1996). The different DBH classes of each species were treated as separate descriptors. In a next step, we substituted space for time to obtain the general successional development of the forest stands in the SNP (Pickett 1989). The time series were merged based on relevé similarity with the method described in detail by Wildi and Schütz (2000). The minimum spanning tree method applied, yielded the order of the merging stages, and the number of relevés corresponding to the same point in time (Gower and Ross 1969; Wildi and Schütz 2000). All relevés belonging to the same point in time were averaged. For each average relevé we then calculated a stand density index (SDI) per species and DBH class, using the formula:

$$
S D I=\sum_{i}\left\{\left[\left(D B H_{i} / 25.4\right)^{1.6}\right] * \text { stem }_{i}\right\}
$$

where $D B H_{i}$ is the midpoint of each DBH class, and stem $_{i}$ the number of trees/ha in a particular DBH 
A

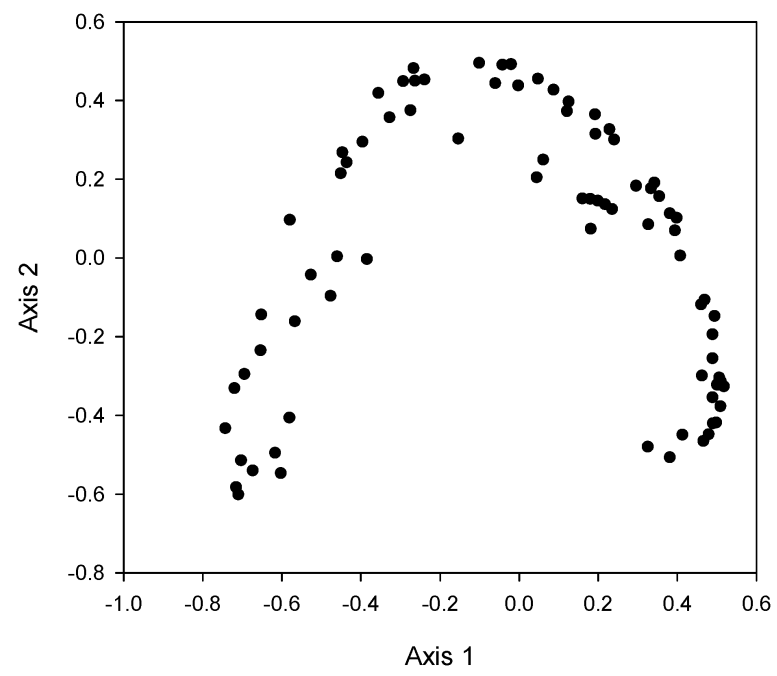

B

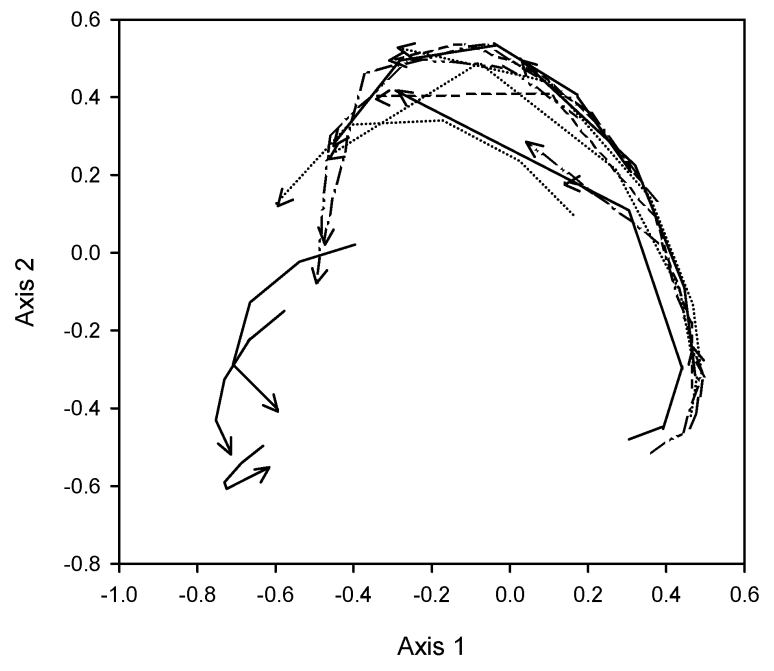

Figure 3. PCoA results derived from 16 time series. Each series consists of two original and three interpolated relevés. The first two axes explain $34.16 \%$ and $21.9 \%$ of the variance, respectively. A: The black dots represent the 80 relevés of the 16 time series. The ones in the lower right corner belong to mountain pine dominated stands, the ones in the lower left to Swiss stone pine/larch dominated stands. B: The 16 arrows represent the temporal development of the 16 different time series. The starting point of each arrow represents a reléve in 1957, while its end point represents the respective reléve in 2001. The longer the arrow, the faster the successional development.

class. For the DBH class bigger than $50 \mathrm{~cm}$, the average of all trees bigger than $50 \mathrm{~cm}$ sampled in 2001 was used for calculations. Since late successional stages are represented by fewer but larger trees than early successional stages, the SDI allows us to compare the different successional stages more easily (Long and Daniel 1990).

\section{Results}

The principal co-ordinate analysis ( $\mathrm{PCoA})$ of the tree and sapling data showed a clear successional trend (Figure 3A). We found that the points in the lower right corner of Figure $3 \mathrm{~A}$ represent stands dominated by mountain pine only, while the points in the lower left corner represent stands dominated by Swiss stone pine or Swiss stone pine/larch (Figure 3A). The speed of successional development varied considerably among the 16 stands, as indicated by the different lengths of the arrows in Figure 3B.

The minimum spanning tree analysis generated a merged time series of eleven successive time stages $\left(t_{1}\right.$ to $\left.t_{11}\right)$. The number of relevés $(n)$ averaged at each time stage were $t_{1}=1, t_{2}=1, t_{3}=4, t_{4}=6, t_{5}=6$, $\mathrm{t}_{6}=12, \mathrm{t}_{7}=16, \mathrm{t}_{8}=13, \mathrm{t}_{9}=9, \mathrm{t}_{10}=9$, and $\mathrm{t}_{11}=$ 3 , respectively. Since the eleven time stages were separated by eleven years (or ten time steps) each, the shortest possible time period needed for the succession from mountain pine to Swiss stone pine or Swiss stone pine/larch forest was 110 years. The tree layer composition at time $\mathrm{t}_{1}$ (time stage one) contained $100 \%$ mountain pine. Larch trees were found first at $t_{3}$, but contributed less than $1 \%$ of the total stems/ha, while Norway spruce and Scots pine appeared first at $t_{4}$, and Swiss stone pine at $t_{5}$. At time stage $t_{11}$ (after ten time steps or 110 years), we found a tree composition (total stems/ha) of $24.8 \%$ mountain pine, $38.5 \%$ Swiss stone pine, $29.6 \%$ larch, and $3.6 \%$ Scots pine and Norway spruce, respectively (Figure 4). Between $t_{1}$ and $t_{11}$ the total number of stems per hectare dropped significantly from 2707 to 492 stems/ha (p $<0.0001$, Figure 4).

The development of SDI between $t_{1}$ and $t_{11}$ of each of the five species and each different DBH class is shown in Figure 5 (A-E). The SDI of mountain pine in DBH classes 0,4 and 5 only changed little over time, while the SDI for classes 1, 2 and 3 decreased considerably between $t_{1}$ and $t_{11}$ (Figure 5A). The strongest decrease was found for trees in DBH class 


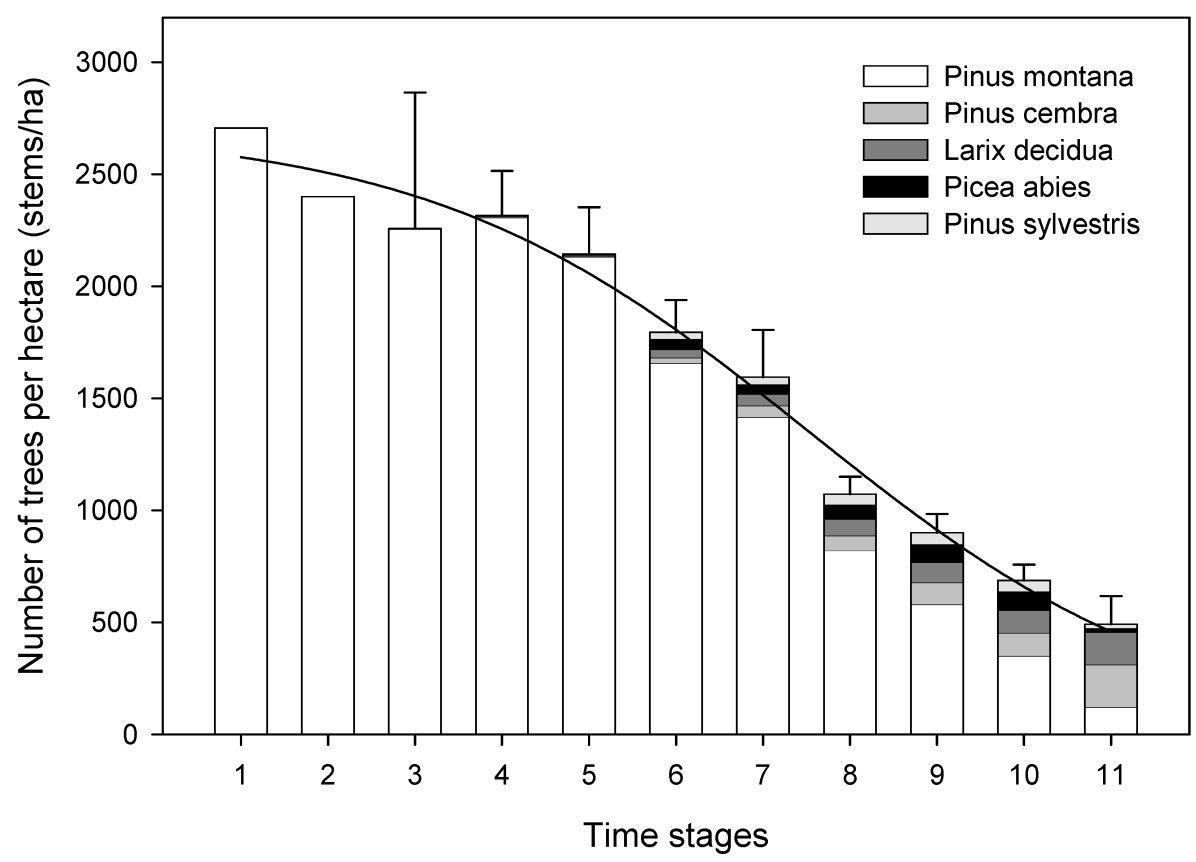

Figure 4. Temporal changes in total number of trees per hectare (total stems/ha) for all species over 11 time stages $\left(t_{1}\right.$ to $\left.t_{11}\right)$. The number of stems/ha are added for each time stage and all species. Standard errors (SE) of the total number of stems/ha are shown as error bars ( $n: t_{1}=$ $1, t_{2}=1, t_{3}=4, t_{4}=6, t_{5}=6, t_{6}=12, t_{7}=16, t_{8}=13, t_{9}=9, t_{10}=9, t_{11}=3$ ), and the sigmoidal regression line is shown in black ( $n$ $\left.=11, \mathrm{r}^{2}=0.985\right)$.

$2(10$ to $19 \mathrm{~cm})$, where the SDI dropped from 384 at $\mathrm{t}_{1}$ to 12 at $\mathrm{t}_{11}$. In contrast, the development of the two late successional species, Swiss stone pine/larch, showed a strong increase in SDI for the DBH classes 4 and 5 after $\mathrm{t}_{5}$, while the SDI for the DBH classes 0 , 1,2 and 3 only changed little over the period studied (Figure 5B, Figure 5C). Temporary increases in SDI were detected for both Scots pine and Norway spruce at mid succession. However, the values for these two species were considerably lower compared to the three tree species, indicating that they do not play a major role during succession in the study area (Figure 5D, Figure 5E).

The development of the relative abundance of saplings (trees between 21 and $130 \mathrm{~cm}$ in height) of all five tree species between $t_{1}$ and $t_{11}$ is shown in Figure 6 . The relative abundance of mountain pine saplings decreased strongly over time $(p<0.0001)$, while the relative number of Swiss stone pine increased significantly $(\mathrm{p}<0.0001$, Figure 6). Mountain pine saplings decreased from $100 \%$ at $\mathrm{t}_{1}$ to only $19.9 \%$ at time stage eleven $\left(t_{11}\right)$. The relative abundance of Swiss stone pine saplings increased from $0 \%$ at $\mathrm{t}_{1}$ to $60 \%$ at $\mathrm{t}_{11}$, while the one of larch and Norway spruce increased from $0 \%$ at $t_{1}$ to $5.3 \%$ and $13.5 \%$ at $t_{11}$, respectively. The relative abundance of Scots pine changed only little over time $(0 \%$ to $1 \%)$.

In order to calculate the approximate age of the forest stands at the beginning of the time series $\left(t_{1}\right)$, we examined how old the trees in mountain pine dominated forest were in 1957. Counting tree rings from cores taken in 2001, we found that mountain pines in DBH class 5 were between 140 to 170 years old. Therefore, the average mountain pine tree in DBH class 5 was calculated to be 95 to 125 years old in 1957 .

\section{Discussion}

The overall goal of this study was to investigate whether successional changes occurred in the mountain pine dominated forests of the SNP during the past 45 years. By examining long-term forest stand data (tree and sapling layer) covering a period of 44 years (1957 to 2001), we found that i) the forest stands studied were in different successional stages and that ii) there is clear evidence that succession from mountain pine to Swiss stone pine or Swiss stone pine/larch 


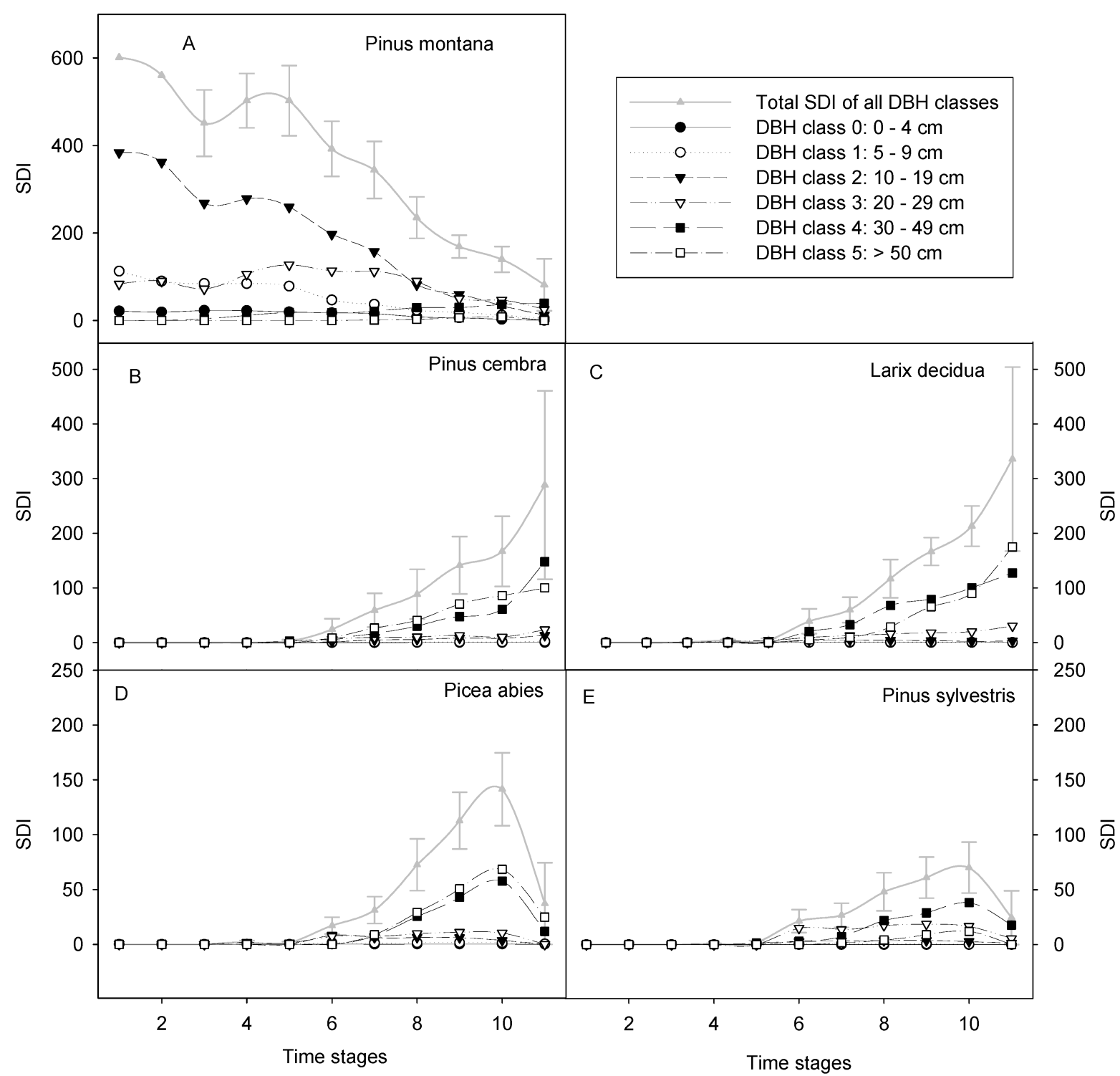

Figure 5. Development of stand density over time. Changes are shown for the total SDI (in grey) of each of the five species and for the SDI of each DBH class and species over 11 time stages $\left(t_{1}\right.$ to $\left.t_{11}\right)$. Standard errors $(S E)$ of total SDI per species are shown as error bars $\left(n\right.$ : $t_{1}=$ $\left.1, \mathrm{t}_{2}=1, \mathrm{t}_{3}=4, \mathrm{t}_{4}=6, \mathrm{t}_{5}=6, \mathrm{t}_{6}=12, \mathrm{t}_{7}=16, \mathrm{t}_{8}=13, \mathrm{t}_{9}=9, \mathrm{t}_{10}=9, \mathrm{t}_{11}=3\right)$. A: mountain pine; B: Swiss stone pine; C: European larch; D: Norway spruce; E: Scots pine.

dominated forests took place. Although disturbances such as infection of mountain pines by root rot fungi (Heterobasidion annosum, Armillaria spp.) were found to significantly affect the development of forest stands in the Park (Dobbertin et al. 2001), they do not appear to effectively prevent the successional development. Likewise, ungulate browsing, another frequent disturbance, does not appear to halt succession toward Swiss stone pine/larch forests. These results agree with other studies conducted in the area (Kienast et al. 1999; Senn 2000; Krüsi and Moser 2000). The same relationship probably holds true for disturbances by snow blight fungus (Phacidium infestans Karst.), windthrows and snow pressure. Consequently, we found that the current level of forest disturbance does not permanently favor the regeneration of only mountain pine. Thus, we were able to empirically support some of the successional changes 


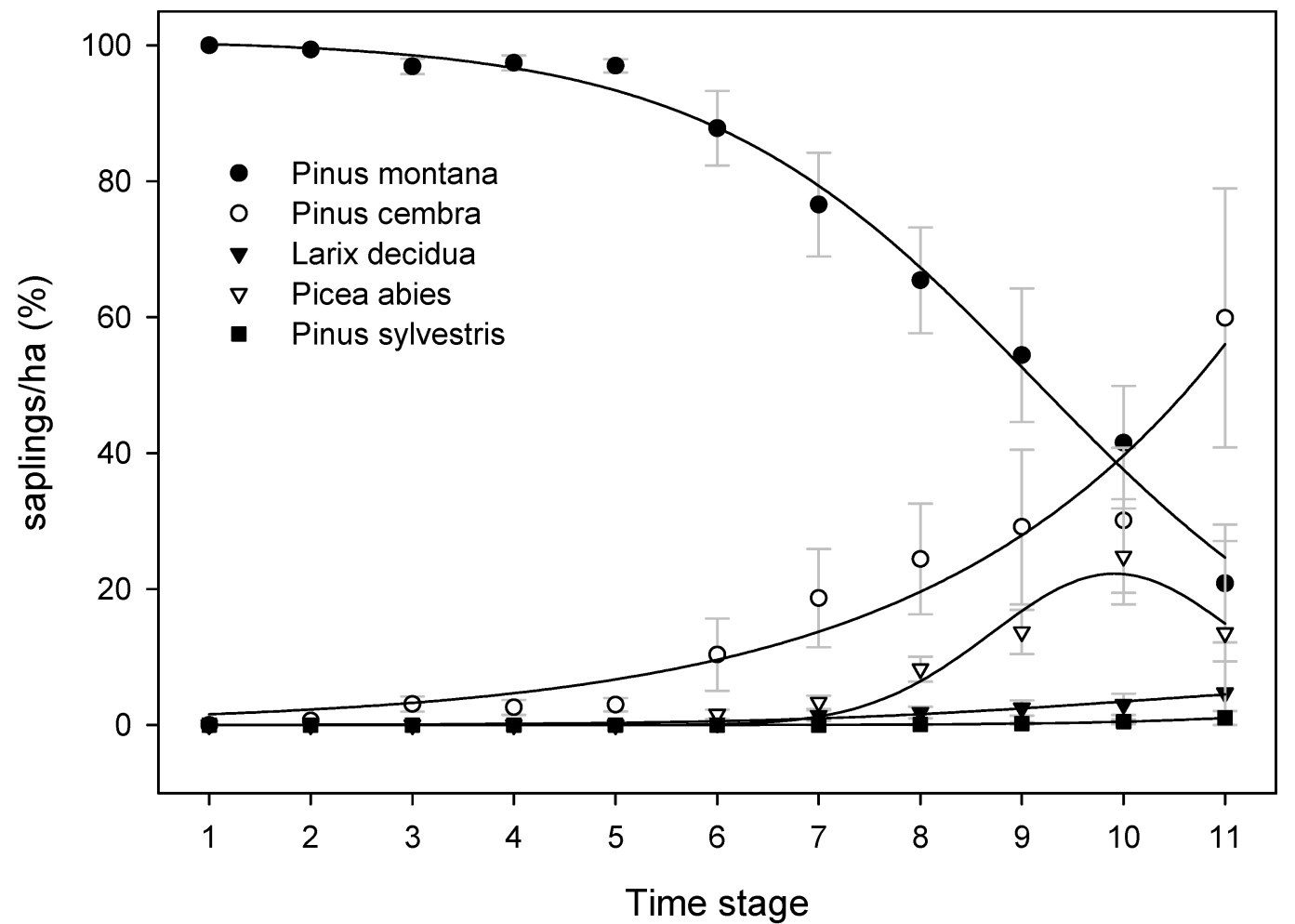

Figure 6. Development of the relative abundance of saplings (\%) between $t_{1}$ and $t_{11}$ for all five species. Standard errors (SE) of the relative abundance of each species are shown as error bars $\left(n: t_{1}=1, t_{2}=1, t_{3}=4, t_{4}=6, t_{5}=6, t_{6}=12, t_{7}=16, t_{8}=13, t_{9}=9, t_{10}=9, t_{11}\right.$ $=3$ ). Regression lines (sigmoidal and gaussian) are shown: $\mathrm{n}=11$ time steps for all five species. $\mathrm{r}_{\text {Pinus montana }}^{2}=0.99$, $\mathrm{r}_{\text {Pinus cembra }}^{2}=0.95$, $\mathrm{r}_{\text {Larix decidua }}^{2}=0.95, \mathrm{r}_{\text {Picea abies }}^{2}=0.95, \mathrm{r}_{\text {Pinus sylvestris }}^{2}=0.99 . \mathrm{p}<0-0001$ for all species.

illustrated in Figure 7. The main ecological forces responsible for the successional development depicted are inter- and intraspecific competition, resulting in i) a reduction in the total number of stems/ha and ii) changes in species composition.

The minimum spanning tree analysis showed that a minimum of 110 years elapses from the early- to the late successional stage. While the 16 stands studied cover an actual time of observation of 44 years each, together they cover a minimum of 110 years of forest succession. Since the tree survey indicated that the average mountain pine forest studied in 1957 had an age of 95 to 125 years, we conclude that a minimum of 205 to 235 years (95 to 125 plus 110 years) after clear-cut is required to reach the late successional Swiss stone pine/larch stage. Swiss stone pine and European larch are known to live 400 to 1200 years (Mayer 1992; Richardson and Rundel 1998) and 400 to 800 years, respectively (McComb 1955; Mayer 1992). Therefore, the late successional species present in the 210 to 240 year old stands today could persist for another 200 to 800 years.

However, the 205 to 235 years reflect the shortest possible pathway for the successional development of subalpine conifer forests of the study area, due to the minimum spanning tree approach applied (Gower and Ross 1969). Wildi and Schütz (2000) emphasized that these time stages should be taken as surrogates for hypothetical rather than actual time units, and should therefore be interpreted with caution. When building a succession model for subalpine grasslands (development from tall-grass/tall-herb meadows to mountain pine forests), they found a time frame of 390 to 580 years, depending on the approach they used. Risch et al. (2001) found a range of 290 to 870 years when applying one of the models by Wildi and Schütz (2000) to a subalpine meadow in the Park. These results show that changes in species composition may proceed at different speed in the same area, making a general assessment of succession rates in the SNP difficult. 


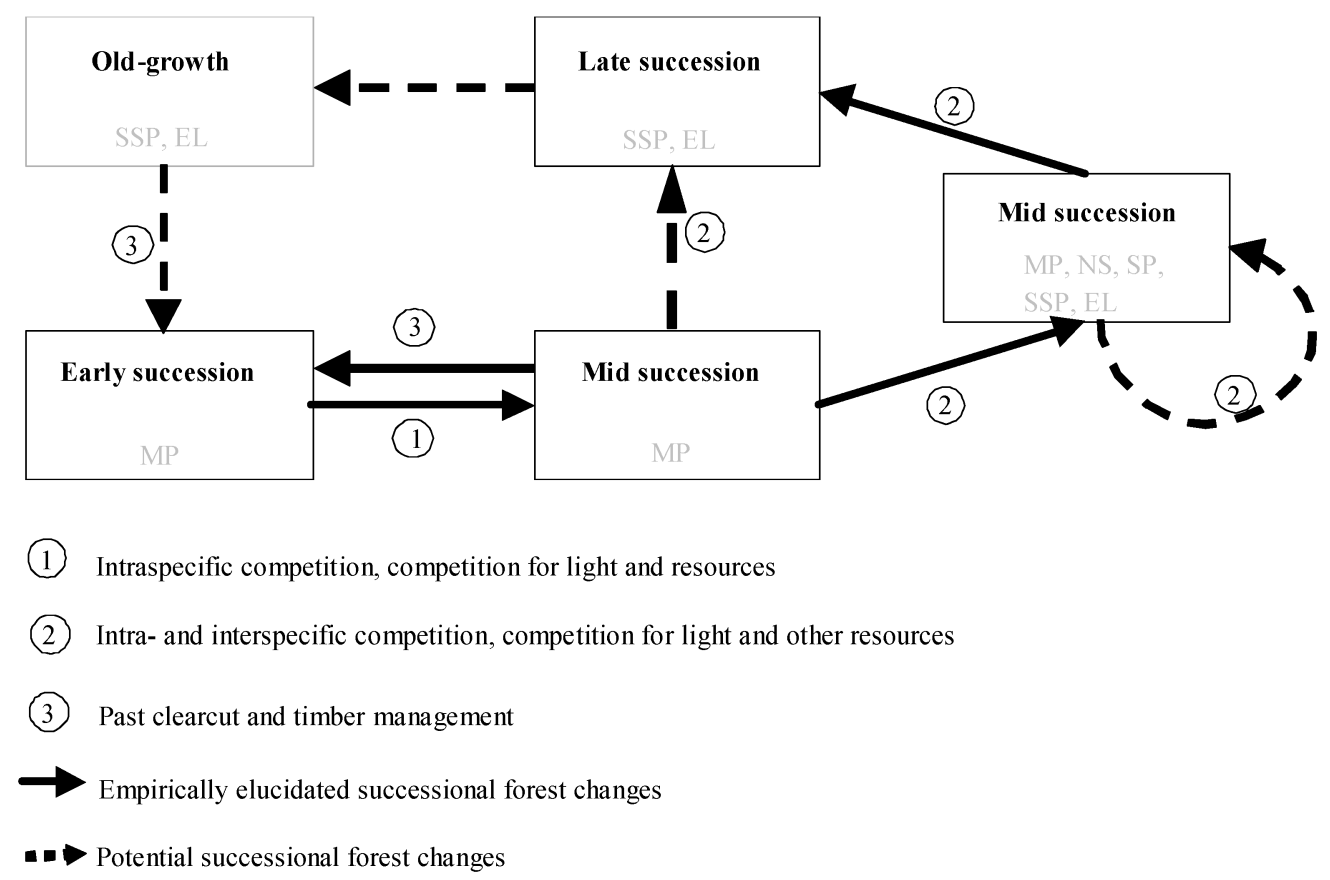

Figure 7. Model of forest succession in the SNP. Empirically delineated changes in tree composition during succession in the SNP are shown with black, solid arrows. Disturbances at the current level of impact were not found to prevent successional changes. The dashed arrows represent other potential changes during succession that were not empirically delineated in this study. Dominating tree species of each successional stage are shown: $\mathrm{MP}=$ mountain pine, $\mathrm{SSP}=$ Swiss stone pine, NS $=$ Norway spruce, EL $=$ European larch, $\mathrm{SP}=\mathrm{Scots}$ pine.

Nevertheless, keeping in mind that the successional phase of 205 to 235 years is an estimate of the fastest possible development of mountain pine forests to Swiss stone pine/larch stands, the forest succession reconstructed in this study requires a similar amount of time as successional changes found in a range of other studies. Along the southern edge of the eastern Alps (Italy), Piussi (1994) and De Mas and Piutti (1994) found that forests entering the late successional stage dominated by Swiss stone pine ranged in age from 200 to 450 years, while Sauermoser (1994) found ranges between 150 and 330 years in the Lechtal Alps, Austria. Smolonogov (1994) suggested that the age of Siberian stone pine (Pinus sibirica Du Tour) forests entering the late successional stage ranged between 180 and 350 years in Eurasia. Keane (2001) modeled succession of subalpine forests in the Western United States, showing that these forests will enter the late successional stage dominated by whitebark pine (Pinus albicaulis Engelm.) within 100 to 200 years. Sala et al. (2001) and Callaway et al. (2000) reported fire intervals averaging 260 years, with a maximum of 458 years in undisturbed white- bark pine forests in the northern Rocky Mountains, USA.

In conclusion, our study depicted the successional trends that are likely to take place in many high elevation areas of the Central European Alps once agricultural or silvicultural management of meadows and forests ceases. This assessment is based on the assumption that the frequency of current disturbances remains similar to the historical level, which clearly is not high enough to keep these forests at an early successional stage (i.e., mountain pine stage).

\section{Acknowledgements}

We thank Dr. Martin F. Jurgensen, Dr. Linda M. Nagel (Michigan Technological University), and Dr. Debbie Page-Dumroese (USDA Forest Service, Rocky Mountain Research Station) for many helpful comments and instructive linguistic adjustments on successive drafts of the manuscript. We are grateful to Sabine Herzog, Christof Elmiger, Florian Risch and several other volunteers for their help during data collection. This study was funded by the Swiss Fed- 
eral Institute of Technology Zurich (grant No. TH-1'/ 01-1) and Swiss Federal Institute for Forest, Snow and Landscape Research. We also would like to express our gratitude to the Swiss National Park Service for the administrative and logistic support of our research in the SNP.

\section{References}

Achermann G., Schütz M., Krüsi B.O. and Wildi O. 2000. Tallherb communities in the Swiss National Park: long-term development of the vegetation. In: Schütz M., Krüsi B.O. and Edwards P.J. (eds), Succession research in the Swiss National Park. Scientific Council of the Swiss National Park, Liestal, pp. 67-88.

Bäntzing W. 1996. Landwirtschaft im Alpenraum - unverzichtbar, aber zukunftslos? In: Bäntzing W. (ed.), Landwirtschaft im Alpenraum - unverzichtbar, aber zukunftslos: Eine alpenweite Bilanz der aktuellen Probleme und der möglichen Lösungen. Blackwell, Berlin, pp. 9-11.

Bärlocher A., Schütz M., Krüsi B.O. and Wildi O. 2000. Development of species richness in mono-dominant colonies of tor grass (Brachypodium pinnatum) - an indicator of the impact of grazing upon subalpine grassland? In: Schütz M., Krüsi B.O. and Edwards P.J. (eds), Succession research in the Swiss National Park. Scientific Council of the Swiss National Park, Liestal, pp. 89-106.

Broggi M.F. 1998. SOS für bedrohte Kulturlandschaften. In: CIPRA (ed.), 1. Alpenreport: Daten, Fakten, Probleme, Lösungsansätze. Haupt, Bern. pp. 152-162.

Callaway R.M., Sala A. and Keane R.E. 2000. Succession may maintain high leaf area: Sapwood ratios and productivity in old subalpine forests. Ecosystems 3: 254-268.

Clements F.E. 1936. Nature and structure of climax. Journal of Ecology 24: 252-284.

De Mas G. and Piutti E. 1994. Structure of Swiss stone pine in northeastern Italy. In: Schmidt W. and Holtmeier F.-K. (eds), Proceedings - International Workshop on subalpine pines and their environment: the status of our knowledge. USDA Forest Service, Odgen, Utah, General Technical Report, INT-GTR-309,. pp. 226-239.

Dobbertin M., Baltensweiler A. and Rigling D. 2001. Tree mortality in an unmanaged mountain pine (Pinus mugo var. uncinata) stand in the Swiss National Park impacted by root rot fungi. Forest Ecology and Management 145: 79-89.

Ellenberg H. 1996. Vegetation Mitteleuropas und der Alpen in ökologischer, dynamischer und historischer Sicht. 5th ed., UTB, Stuttgart.

Gleason H.A. 1926. The individualistic concept of plant association. Bulletin of the Torrey Botanical Club 53: 7-26.

Gower J.C., and Ross G.J.S. 1969. Minimum spanning tree and single linkage cluster analysis. Applied Statistics 18: 54-64.

Greig-Smith P. 1983. Quantitative plant ecology. 3rd ed. Blackwell, Oxford.

Holtmeier F.-K. 1990. Disturbance and management problems in larch-cembra pine forests in Europe. In: Schmidt W. and McDonald K.J. (eds), Proceedings - Symposium on whitebark pine ecosystems: Ecology and management of a high-mountain resource. USDA Forest Service, Odgen, Utah, General Technical Report, INT-GTR-270, pp. 25-36.

Keane R.E. 2001. Successional dynamics: modeling an anthropogenic threat. In: Tomback D.F., Arno S.F., and Keane R.E. (eds), Whitebark pine communities: ecology and restoration. Island Press, Washington, D.C., pp. 159-192.

Keller W., Wohlgemuth T., Kuhn N., Schütz M. and Wildi O. 1998. Waldgesellschaften der Schweiz auf floristischer Grundlage. Mitteilungen der Eidgenössischen Forschungsanstalt für Wald, Schnee und Landschaft 73: 93-357.

Kienast F., Fritschi J., Bissegger M. and Abderhalden W. 1999. Modeling successional pattern of high-elevation forests under changing herbivore pressure - responses at the landscape level. Forest Ecology and Management 120: 35-46.

Krüsi B.O. and Moser B. 2000. Impacts of snow and ungulates on the successional development of a mountain pine forest in the Swiss National Park. In: Schütz M., Krüsi B.O. and Edwards P.J. (eds), Succession research in the Swiss National Park. Scientific Council of the Swiss National Park, Liestal, pp. 131-164.

Krüsi B.O., Schütz M., Grämiger H. and Achermann G. 1996. Was bedeuten Huftiere für den Lebensraum Nationalpark? Eine Studie zu Nahrungsangebot und Waldverjüngung. Cratschla 4: 51-64.

Kurth A., Weidmann A. and Thommen F. 1960. Beitrag zur Kenntnis der Waldverhältnisse im Schweizerischen Nationalpark. Mitteilungen der Schweizerischen Anstalt für das forstliche Versuchswesen 36: 221-379.

Lauber L. and Wagner G. 1996. Flora Helvetica. Paul Haupt, Bern.

Long J.N. and Daniel T.W. 1990. Assessment of growing stock in uneven-aged stands. Western Journal of Applied Forestry 5: 9396.

Märki K., Nievergelt B., Gigon A. and Schütz M. 2000. Impact of selective foraging by red deer on the long-term vegetation development in the Swiss National Park. In: Schütz M., Krüsi B.O. and Edwards P.J. (eds), Succession research in the Swiss National Park. Scientific Council of the Swiss National Park, Liestal, pp. 189-206.

Mayer H. 1992. Waldbau auf soziologischer-ökologischer Grundlage. Fischer, Stuttgart.

McComb A.L. 1955. The European larch: its races, site requirements and characteristics. Forest Science 1: 298-318.

Parolini J.D. 1995. Zur Geschichte der Waldnutzung im Gebiet des heutigen Schweizerischen Nationalparks. Ph.D. Thesis, Eidgenössische Technische Hochschule, Zürich.

Pickett T.A. 1989. Space-for-time substitution as an alternative to long-term studies. In: Likens E. (ed.), Long-term studies in ecology: Approaches and alternatives. Springer, New York, NY. pp. $110-135$.

Piussi P. 1994. Mixed cembran pine stands on the southern slope of the Eastern Alps. In: Schmidt W. and Holtmeier F.-K. (eds), Proceedings - International Workshop on subalpine pines and their environment: the status of our knowledge. USDA Forest Service, Odgen, Utah, General Technical Report, INT-GTR-309, pp. 261-268.

Price M.F. 1995. Mountain research in Europe: an overview of MAB Research from the Pyrenees to Siberia. In: Jeffers J.N.R. (ed.), Man and the Biospheres Series. UNESCO, Paris.

Richardson D.M. and Rundel P.W. 1998. Ecology and biogeography of Pinus: an introduction. In: Richardson D.M. (ed.), Ecology and biogeography of Pinus. Cambridge University Press, Cambridge, pp. 3-46. 
Riederer P. 1996. Berglandwirtschaft in der Schweiz. In: Bäntzing W. (ed.), Landwirtschaft im Alpenraum - unverzichtbar, aber zukunftslos: Eine alpenweite Bilanz der aktuellen Probleme und der möglichen Lösungen. Blackwell, Berlin, pp. 117-139.

Risch A.C., Krüsi B.O., Grämiger H. and Schütz M. 2001. Spatially specific simulation of the long-term development of a subalpine pasture in the Swiss National Park. Bulletin of the Geobotanical Institute ETH 67: 27-40.

Sala A., Carey E.V., Keane R.E. and Callaway R.M. 2001.Water use by whitebark pine and subalpine fir: potential consequences of fire exclusion in the northern Rocky Mountains. Tree Physiology 21: 717-725.

Sauermoser S. 1994. Current distribution of cembra pine in the Lechtal Alps. In: Schmidt W. and Holtmeier F.-K. (eds), Proceedings - International Workshop on subalpine pines and their environment: the status of our knowledge. USDA Forest Service, Odgen, Utah, General Technical Report, INT-GTR-309, pp. 269-274.

Schütz M., Wildi O., Achermann G., Krüsi B.O. and Nievergelt B. 2000a. Predicting the development of subalpine grassland in the Swiss National Park: how to build a succession model based on data from long-term permanent plots. In: Schütz M., Krüsi B.O. and Edwards P.J. (eds), Succession research in the Swiss National Park. Scientific Council of the Swiss National Park, Liestal, pp. 207-236.

Schütz M., Wildi O., Krüsi B.O., Märki K. and Nievergelt B. 2000b. From tall-herb communities to pine forest: distribution patterns of 121 plant species during a 585 year regeneration process. In: Schütz M., Krüsi B.O. and Edwards P.J. (eds), Succes- sion research in the Swiss National Park. Scientific Council of the Swiss National Park, Liestal, pp. 237-255.

Schütz M., Wolgemuth T., Achermann G., Krüsi B.O. and Wildi O. 2000c. Influence of increasing grazing pressure on species richness in subalpine grassland in the Swiss National Park. In: Schütz M., Krüsi B.O. and Edwards P.J. (eds), Succession research in the Swiss National Park. Scientific Council of the Swiss National Park, Liestal, pp. 67-88.

Senn J. 2000. Huftiere und Verjüngung im Gebirgswald: eine Geschichte mit vielen Variablen und noch mehr Interaktionen. Schweizerische Zeitschrift für das Forstwesen 151: 99-106.

Smolonogov E.P. 1994. Geographical differentiation and dynamics of Siberian stone pine forests in Eurasia. In: Schmidt W. and Holtmeier F.-K. (eds), Proceedings - International Workshop on subalpine pines and their environment: the status of our knowledge. USDA Forest Service, Odgen, Utah, General Technical Report, INT-GTR-309, pp. 275-279.

Watt A.S. 1947. Patterns and processes in the plant community. Journal of Ecology 35: 1-22.

Wildi O. and Orlóci L. 1996. Numerical exploration of community patterns. A guide to the use of MULVA-5. SPB Academic Publisher, The Hague.

Wildi O. and Schütz M. 2000. Reconstruction of a long-term recovery process from pasture to forest. Community Ecology 1: 25-32.

Zoller H. 1995. Vegetationskarte des Schweizerischen Nationalparks. Erläuterungen. Nationalpark - Forschung Schweiz. 85: $1-108$. 